\title{
Sensory response of the egg parasitoid Telenomus podisi to stimuli from the bug Euschistus heros
}

\author{
Cleonor Cavalcante Silva ${ }^{(1)}$, Maria Carolina Blassioli Moraes ${ }^{(1)}$, Raúl Alberto Laumann $^{(1)}$ \\ and Miguel Borges ${ }^{(1)}$
}

\begin{abstract}
(1)Embrapa Recursos Genéticos e Biotecnologia, Parque Estação Biológica, Av. W5 Norte (Final), Asa Norte, Caixa Postal 02372, CEP 70770-900 Brasília, DF, Brazil. E-mail: cleonor@cenargen.embrapa.br, mcbmorae@cenargen.embrapa.br, laumann@cenargen.embrapa.br, mborges@cenargen.embrapa.br
\end{abstract}

\begin{abstract}
The objective of this work was to study the foraging behavior of Telenomus podisi Ashmead (Hymenoptera: Scelionidae) in the presence of stimuli from its host, Euschistus heros (Heteroptera: Pentatomidae). The stimuli selected were: egg mass; virgin males and females; volatile extracts of sexually mature males and females; components of male sex pheromone; a component of the alarm pheromone, hexane and an empty cage as control. In a closed arena, the parasitoids were given the choice between single and combined stimuli presented to them simultaneously. To find the host egg, $T$. podisi primarily uses the sensory cues released from the male insects. The orientation toward odors of male chemical extract indicates that a source of kairomone was detected. Gas chromatographic analyses of this substance showed peak of methyl 2,6,10-trimethyltridecanoate, the main component of male sexual pheromone. The sensory response to methyl 2,6,10-trimethyltridecanoate confirms that this compound may act as a kairomone to find host eggs. Females and egg mass stimuli were weakly attractive to the parasitoid.
\end{abstract}

Index terms: forage behavior, sex pheromone, olfactory response, combination of stimuli.

\section{Resposta sensorial do parasitóide de ovos Telenomus podisi a estímulos provenientes do percevejo Euschistus heros}

\begin{abstract}
Resumo - O objetivo deste trabalho foi estudar o comportamento de busca de Telenomus podisi Ashmead (Hymenoptera: Scelionidae), em presença de estímulos provenientes do hospedeiro Euschitus heros (Heteroptera: Pentatomidae). As fontes de estímulos utilizadas foram: massas de ovos, machos e fêmeas virgens, extratos químicos de machos e fêmeas sexualmente maduros, componentes sintéticos do feromônio sexual do macho de E. heros, um composto sintético do feromônio de alarme, hexano e uma gaiola vazia como controle. Os testes foram conduzidos em arenas, onde foi dada a oportunidade para os parasitóides escolherem entre estímulos isolados e estímulos combinados. Para encontrar o hospedeiro, T. podisi utiliza principalmente estímulos olfativos emitidos pelos machos. As respostas sensoriais aos odores liberados pelos extratos químicos do macho indicam que uma fonte de cairomônio foi detectada. Análises cromatográficas mostraram picos do composto metil 2,6,10-trimetiltridecanoato, principal componente do feromônio sexual do macho de $E$. heros. As respostas olfativas a metil 2,6,10-trimetiltridecanoato confirmam que este composto pode agir como cairomônio para encontrar o hospedeiro. Estímulos provenientes das fêmeas virgens e de massas de ovos foram pouco atrativos ao parasitóide.
\end{abstract}

Termos para indexação: comportamento de busca, feromônio sexual, resposta olfativa, combinação de estímulos.

\section{Introduction}

Because of direct implications on biological control, studies on insect sensory responses are important to understand the interactions between the foraging behavior of parasitoids and their host-plant complex. In these interactions, the parasitoid has to learn to discriminate many different cues related to the presence of the host, especially chemical cues (Wackers \& Lewis, 1994; Larsson \& Svensson, 2004).
Chemical and physical cues derived directly from the host are generally the most reliable source of information, because they can inform the parasitoid of the presence, availabity and suitability of the host (Du et al., 1996).

Herbivore-induced cues are also important for the foraging success of parasitoids and for plant defense (Hilker et al., 2000). These substances are produced in minute amounts and must be discriminated from a wide range of odors in the environment (Du et al., 1996). For example, the egg parasitoid Trissolcus basalis 
(Wollaston) (Hymenoptera: Scelionidae) depends largely on olfactory cues released from its adult host, Nezara viridula (Heteroptera: Pentatomidae), such as the male sex pheromone (Colazza et al., 1999; Conti et al., 2003). As the parasitoid gets closer, nonvolatile stimuli provide additional information about the host, such as the adhesive secretion that attaches eggs to the substrate (Conti et al., 2003). This secretion has shown to act as kairomone, which the parasitoid learns to associate to the presence of the host egg (Colazza et al., 1999; Conti et al., 2003). For long-range attraction, the parasitoid uses plant volatile chemicals induced by host feeding and oviposition (Mattiacci et al., 1993; Colazza et al., 2004).

Similar strategies are used by another species of egg parasitoid, Trissolcus brochymenae (Ashmead) towards its host, Murgantia histrionica (Heteroptera: Pentatomidae). In short range bioassays, females of this parasitoid respond to volatile compounds from fifth instar nymphs and to paths contaminated by chemicals left by the host (Conti et al., 2003).

Among the egg parasitoids of pentatomids, Telenomus podisi (Hymenoptera: Scelionidae) has been received a considerable attention due to its potential as a biological control agent of the stink bug, Euschistus heros (Heteroptera: Pentatomidae), an important pest of soybean in Brazil (Peres \& Corrêia-Fereira, 2004).

The foraging behavior of this parasitoid has been studied both in the field and laboratory (Pires et al., 2001; Sujii et al., 2002; Borges et al., 2003). At least three sources of kairomones from $E$. heros have been found by Borges et al. (1999, 2003). In the laboratory, the influence of male sex pheromone on the searching behavior of the parasitoid has been reported (Borges et al., 1999).

Tactile cues are also used by the parasitoid, since it is able to distinguish between fertile and infertile host eggs, which are different in shape and size (Borges et al., 1999). Recently, it was demonstrated that this parasitoid recognizes specifically traces left on the substrate by the walking of E. heros females, and then searches intensively the area of the footprints, apparently looking for the host egg (Borges et al., 2003). The parasitoid also recognizes volatiles from soybean and pigeon bean (Cajanus cajan) plants damaged by E. heros (Moraes et al., 2005).

All these sensory-mediated behaviors were studied, using one or two sources of stimuli at a time. When searching for egg host within the host habitat, parasitoids use a variety of sensory stimuli to gather information from their host. Thus, the role of a specific sensory modality on the searching behavior of a parasitoid should be understood, before any biological control strategy is implemented, which would help to develop techniques for attraction and conservation of the parasitoid in the host habitat.

The objective of this work was to study the foraging behavior of $T$. podisi, in the presence of stimuli combination from $E$. heros.

\section{Material and Methods}

E. heros was reared in $5 \mathrm{~L}$ plastic containers, on fresh green beans (Phaseolus vulgaris), soybeans (Glycine max), sunflower seeds (Helianthus annus), raw peanuts (Arachis hypogaea) and water renewed twice a week. To provide oviposition substrate and shelter for the bugs, a nylon mesh screen was placed inside the cages. Egg masses were collected daily and incubated in Petri dishes until nymphs reached the second instar. At this time, nymphs were transferred to new plastic containers and reared as described until the adult stage.

T. podisi was obtained from parasitized eggs of E. heros. The parasitoids were maintained in an environmental room, in acrylic cages (tissue culture $25 \mathrm{~cm}^{2}$ flask, angle neck) and fed with a drop of honey, supplied three days per week. Two-day old females with oviposition experience were used in the experiments. Experience was obtained by exposing naive females to freshly laid egg masses (30 eggs), which were glued to cardboard strips and then inserted into a glass tube for parasitizing for 24 hours. After this period, the strips were removed to a new tube for incubation. Both $E$. heros and T. podisi were maintained in the environmental room at $27 \pm 1^{\circ} \mathrm{C}, 65 \pm 5 \% \mathrm{RH}$ and 14 hours photophase.

The experiments were done in square acrylic boxes $(24 \times 24 \times 8 \mathrm{~cm})$, called multiple choice arenas, in which the stimuli were tested simultaneously for their attractiveness to the parasitoid. In each corner of the arena, it was placed a circular mesh box ( $4 \mathrm{~cm}$ diameter $\mathrm{x} 8 \mathrm{~cm}$ high) that served as a cage to hold the host and to separate each source of stimuli. A square opening of $17 \times 17 \mathrm{~cm}$ on the lid, covered with 3-mm mesh avoided saturation of the internal environment.

The sources of stimuli used were: host egg masses with thirty eggs; virgin males and females of $E$. heros; volatile extracts of sexually mature males and females of E. heros; the synthetic components of male sex pheromone of $E$. heros; a synthetic compound of alarm 
pheromone of $E$. heros; hexane and an empty cage as control.

To collect the chemical extracts, groups of 40 sexually mature female or male $E$. heros were placed in 3 L glass containers adapted for the aeration procedure. On the lid of the containers, two holes were made for insertion of glass tubes ( $8 \mathrm{~cm}$ length, $0.7 \mathrm{~cm}$ diameter) containing $60 \mathrm{mg}$ of Super Q adsorbent (Alltech 80/100 mesh). The traps were then attached to a vacuum line by silicone tubing. Purified air was drawn through each aeration chamber at a rate of $1,200 \mathrm{~mL} \mathrm{~min}{ }^{-1}$. The bugs were allowed to feed during volatiles collection. The collection was carried out for 24 hours and the volatile were collected daily. The trap was rinsed with $2 \mathrm{~mL}$ of hexane (solvent). The excess solvent was evaporated under pure $\mathrm{N}_{2}$ to yield approximately $200 \mu \mathrm{L}$ of the solution, corresponding to a concentration of approximately 0.1 individual equivalent (I.E) $\mu \mathrm{L}^{-1}$ of solution to be tested.

Inside the arenas, the experimental design (stimuli combination) was: live insects (virgin males, virgin females, virgin males + virgin females, an empty cage); live insects vs. egg mass (virgin males + egg mass, virgin females + egg mass, virgin males + virgin females + egg mass, and egg mass); adults chemical extracts vs. alarm pheromone (male extract, female extract, (E)-2-hexenal and hexane); chemical extracts vs. alarm pheromone vs. egg mass (male extract + egg mass, female extract + egg mass, (E)-2-hexenal + egg mass and hexane); live insects vs. synthetic components of sex pheromone (males, methyl 2,6,10-trimethyltridecanoate, hexane, an empty cage; males, methyl 2,6,10-trimethyldodecanoate, hexane, empty cage; males, 2,4-decadienoate, hexane, empty cage); the synthetic components of sex pheromone (methyl 2,6,10-trimethyltridecanoate; methyl 2,6,10-trimethyldodecanoate, 2,4-decadienoate, hexane).

Two male and two female of E. heros (12 days old) were used in the experiments. The chemical extracts were presented to the parasitoids on strips of filter paper (2x0.5 cm), on which $5 \mu \mathrm{L}$ of the solution $(0.5$ insect equivalents) were placed. The filter papers were then placed in the boxes inside the arenas. The same volume $(5 \mu \mathrm{L})$ of (E)-2-hexenal, methyl 2,6,10-trimethyltridecanoate, methyl 2,6,10-trimethyldodecanoate, 2,4-decadienoate (10 ppm) and hexane were used. The dose of $5 \mu \mathrm{L}$ had been tested before and proved to be attractive to T. podsi. Female parasitoids were liberated individually in the center of the arenas, and their behavior (direction of walk, box entering, stimuli visited) was monitored for 15 minutes. First choice was considered the stimuli preferred. Females that flew to the top of the arena or made no choice were considered to have no response. After every experiment, the position of the odor sources was randomized. Females were used only once. Observations were made at fluorescent light, $27 \pm 1^{\circ} \mathrm{C}$ and $65 \pm 5 \% \mathrm{RH}$. Differences in the total number of choices, made by parasitoids to different treatments within each arena experiment, were analyzed by the $\chi^{2}$ test. For each experiment, 117 females were tested.

\section{Results and Discussion}

The responses of $T$. podisi to a combination of sensory stimuli from E. heros are shown in Figures 1 and 2. There was a significant olfactory response $\left(\chi^{2}=19.77\right.$, $\mathrm{df}=3, \mathrm{~N}=117, \mathrm{p}<0.001$ ), when comparing the choices of the parasitoids to virgin males or virgin males + virgin females with the responses to virgin females or the empty cage. During the first 10 minutes of the experiment, female parasitoids explored the entire arena and spent most of the time near the cages where males were present. This result is in disagreement with reports in the literature.

Conti et al. (2003), studying the foraging behavior of T. brochymenae (in Y-tube olfactometer), reported that chemical cues released from virgin females $M$. histrionica were attractive to the parasitoid. In the present work, sensory stimuli originating from $E$. heros females were weakly active to the parasitoid, but in combination with males the behavior of the parasitoid changed significantly. E. heros male differs chemically from the female because of sex pheromones, and the parasitoid may have learned to associate sex pheromone with the presence of host egg. Borges et al. (1998) reported that the male-produced pheromone of $E$. heros is apparently attractive to the parasitoid at both long and short-distances. The odor of pheromone may lead the parasitoid to the area where the host egg probably is.

When the host egg was combined with either males or females or males + females or kept alone, the pattern of response was similar. The great majority of $T$. podisi females responded to the olfactory cues originating from males + eggs $\left(\chi^{2}=19.47 ; \mathrm{N}=117 ; \mathrm{df}=3 ; \mathrm{p}=0.002\right)$ (Figure $1 \mathrm{~B}$ ). Egg masses alone caused little attraction in the parasitoid, but their combination with other stimuli increased the stimulation. The absence of orientation toward egg masses in arenas confirms previous reports 
that chemical cues from scelionid host eggs are nonvolatile and are used to recognize the host at short distances (<1 mm) (Bin et al., 1993; Borges et al., 1999).

Parasitoids exposed to adult extracts with or without host eggs and to the component of alarm pheromone [(E)-2-hexenal] with or without host eggs showed a significant preference for odors from male extract $\left(\chi^{2}=28.99 ; \mathrm{df}=3 ; \mathrm{N}=114 ; \mathrm{P}=0.001\right)$ (Figure 1 C) and odors from male extract + host eggs $\left(\chi^{2}=13.87\right.$; $\mathrm{N}=117$; $\mathrm{df}=3 ; \mathrm{P}<0.003$ ) (Figure $1 \mathrm{D}$ ), when compared to their responses to female extract either alone or with eggs. These responses were similar to those of live males and suggest that a recognition kairomone was detected. Gas chromatographic analyses of the male extracts showed the peaks of the methyl 2,6,10-trimethyltridecanoate, which is the main component of the male sex pheromone of E. heros. Pires et al. (2001), studying the kairomonal effect of alarm pheromone of Nezara viridula and Piezodorus guildini on T. podisi, demonstrated that (E)-2-hexenal affects positively the oviposition behavior of $T$. podisi.
In the present work, (E)-2-hexenal did not affect the foraging behavior of $T$. podisi, when tested against males extracts (Figure $1 \mathrm{C}$ and D).

When individual sex pheromone components were tested in the presence of male insects, there was a significant response $\left(\chi^{2}=63.85 ; \mathrm{df}=3 ; \mathrm{N}=39 ; \mathrm{P}=0.001\right)$ to synthetic methyl 2,6,10-trimethyltridecanoate (Figure $2 \mathrm{~A}$ ). This confirms previous assumption that this compound is used by the parasitoids to locate the host (Borges et al., 1999). There was no significant response among the other components of the sex pheromone: methyl 2,6,10-trimethyldodecanoate and 2,4 decadienoate and the male insects (Figure 2 B and C). Finally, when the individual components of sex pheromone were offered to $T$. podisi females, methyl 2,6,10-trimethyltridecanoate, although not significant, was preferred to others.

In this study, T. podisi primarily used olfactory cues from E. heros males to find the host egg. In all experiments where male or male chemical extract was present, the response of parasitoid was higher than the
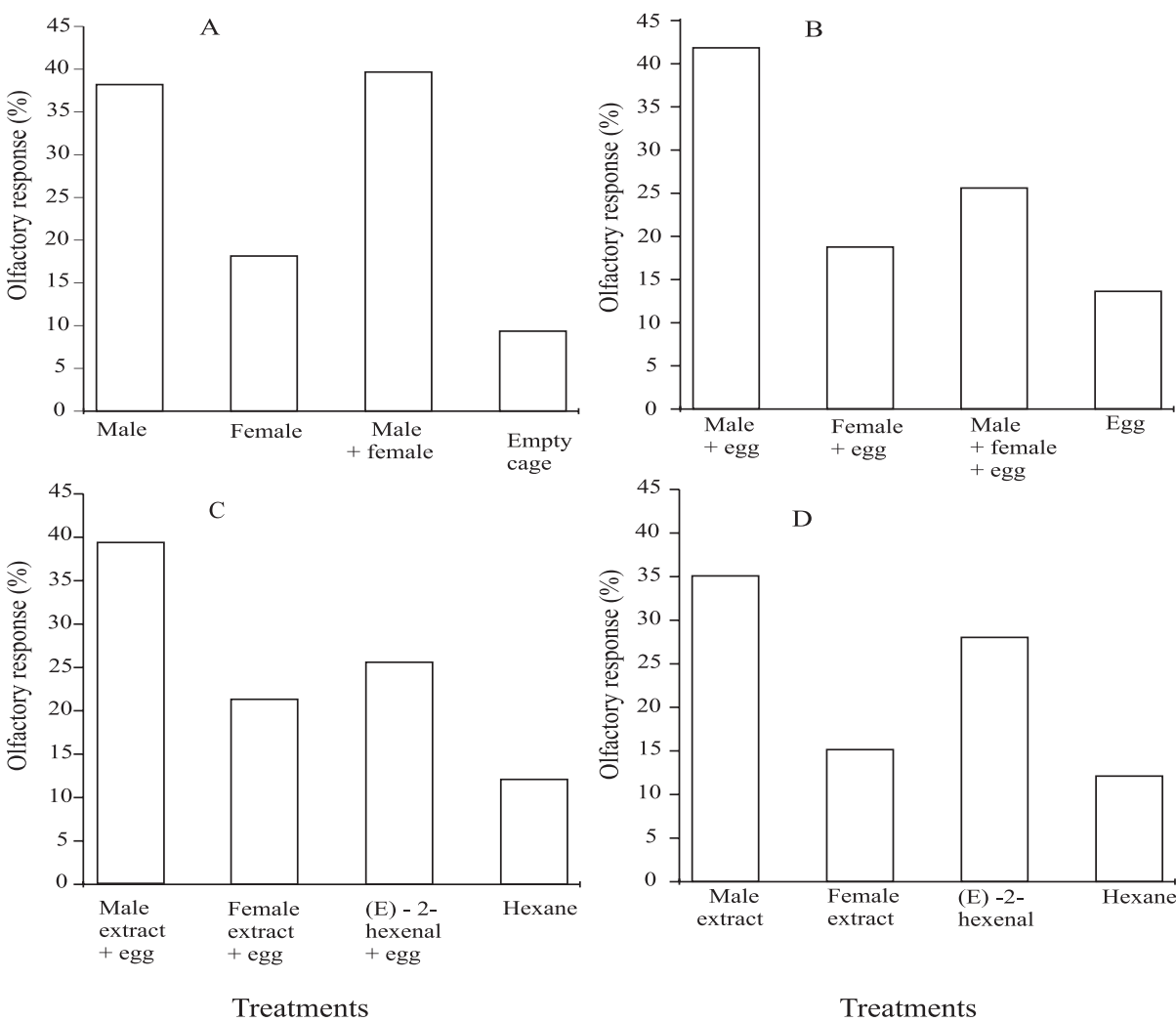

Figure 1. Percentage of Telenomus podisi responses to sensory stimuli from Euschistus heros and chemical extracts, in multiple choice arena experiments. The $\chi^{2}$ test showed a significant response $(\mathrm{p}<0.001)$ to the presence of male and chemical male extract due to the most of parasitoids being oriented to these stimuli. 

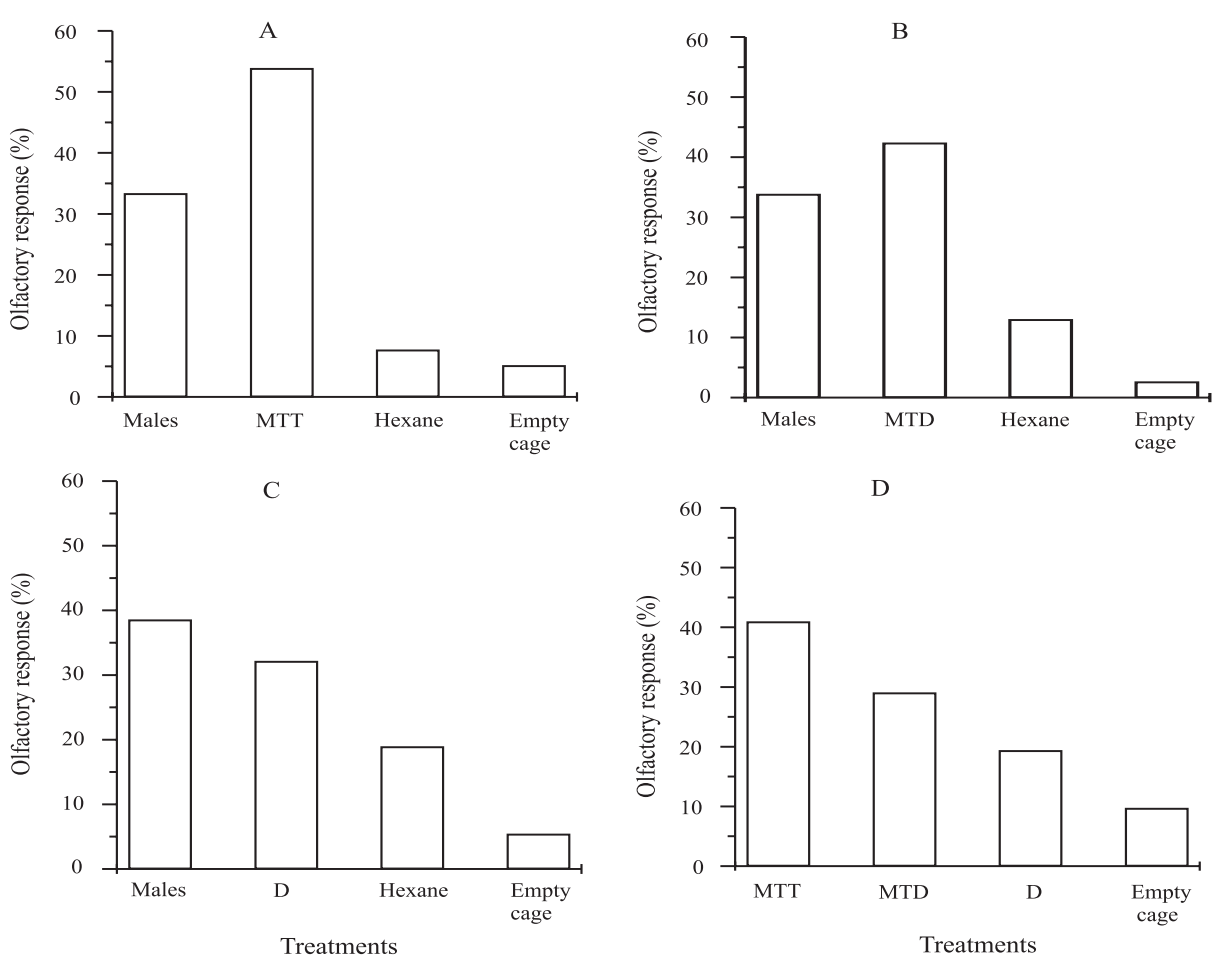

Figure 2. Percentage of Telenomus podisi responses to olfactory stimuli from the synthetic components of Euschistus heros male sex pheromone, when presented alone or in the presence of males. MTT (methyl 2,6,10-trimethyltridecanoate); MTD (methyl 2,6,10-trimethyldodecanoate); D (2,4-decadienoate). The $\chi^{2}$ showed a significant response $(\mathrm{p}=0.001)$ to the compound MTT.

other treatments. From these results, the principal component of E. heros male sex pheromone, methyl 2,6,10-trimethyltridecanoate, showed to be the main signal used by $T$. podisi during its foraging behavior. Additional research needs to be carried out to elucidate the ecological and adaptative context of the use of sex pheromone components by scelionid wasps.

\section{Conclusions}

1. In its foraging behavior, Telenomus podisi uses sensory stimuli from male Euschistus heros; at long distances, females and egg masses alone are weakly attractive to the parasitoid when searching for the host.

2 . If the host egg produces any sensory information, it may be used to locate the host over short distances for host recognition and selection.

3 . The synthetic sex pheromone component methyl 2,6,10-trimethyltridecanoate is used as a kairomone during the searching behavior of Telenomus podisi; this compound is preferred to other components of the sex or alarm pheromones of Euschistus heros.

\section{References}

BIN, F.; VINSON, S.B.; STRAND, M.R.; COLAZZA, S.; JONES JUNIOR, W.A. Source of an egg kairomone for Trissolcus basalis, a parasitoid of Nezara viridula. Physiological Entomology, v.18, p.7-15, 1993.

BORGES, M.; COLAZZA, S.; RAMIREZ-LUCAS, P.; CAUHAN, K.R.; MORAES, M.C.B.; ALDRICH, J.R. Kairomonal effect of walking traces from Euschistus heros (Heteroptera: Pentatomidae) on two strains of Telenomus podisi (Hymenoptera: Scelionidae). Physiological Entomology, v.28, p.349-355, 2003.

BORGES, M.; COSTA, M.L.M.; SUJII, E.R.; CAVALCANTI, M. das G.; REDIGOLO, G.F.; RESCK, I.S.; VILELA, E.F. Semiochemical and physical stimuli involved in host recognition by Telenomus podisi (Hymenoptera: Scelionidae) toward Euschistus heros (Heteroptera: Pentatomidae). Physiological Entomology, v.24, p.227-233, 1999.

BORGES, M.; MORI, K.; COSTA, M.L.M.; SUJII, E.R. Behavioural evidence of methyl 2, 6, 10-trimethyltridecanoate as a sex pheromone of Euschistus heros (Heteroptera: Pentatomidae). Journal of Applied Entomology, v.122, p.101-106, 1998.

COLAZZA, S.; McELFRESH, J.S.; MILLAR, J.G. Identification of volatile synomones, induced by Nezara viridula feeding and 
oviposition on bean spp., that attract the egg parasitoid Trissolcus basalis. Journal of Chemical Ecology, v.30, p.945-964, 2004.

COLAZZA, S.; SALERNO, G.; WAJNBERG, E. Volatile and contact chemicals released by Nezara viridula (Heteroptera: Pentatomidae) have a kairomonal effect on the egg parasitoid Trissolcus basalis (Hymenoptera: Scelionidae). Biological Control, v.16, p.310-317, 1999.

CONTI, E.; SALERNO, G.; BIN, F.; WILLIAMS, H.J.; VINSON, S.B. Chemical cues from Murgantia histrionica eliciting host location and recognition in the egg parasitoid Trissolcus brochymenae. Journal of Chemical Ecology, v.29, p.115-130, 2003.

DU, Y.J.; POPPY, G.M.; POWELL, W. Relative importance of semiochemicals from first and second trophic levels in host foraging behavior of Aphidius ervi. Journal of Chemical Ecology, v.22, p.1591-1605, 1996.

HILKER, M.; BLÄSKE, V.; KOBS, C.; DIPPEL, C. Kairomonal effects of sawfly sex pheromones on egg parasitoids. Journal of Chemical Ecology, v.26, p.2591-2601, 2000.

LARSSON, M.C.; SVENSSON, G.P. Methods in insect sensory ecology. In: CHRISTENSEN, T.A. (Ed.). Methods in insect sensory neuroscience. Boca Raton: CRC Press, 2004. p.25-55.

MATTIACCI, L.; VINSON, S.B.; WILLIAMS, H.J.; ALDRICH, J.R.; BIN, F. A long-range attractant kairomone for egg parasitoid Trissolcus basalis, isolated from defensive secretion of its host Nezara viridula. Journal of Chemical Ecology, v.19, p.1167-1181, 1993.
MORAES, M.C.B.; LAUMANN, R.; SUJII, E.R.; PIRES, C.; BORGES, M. Induced volatiles in soybean and pigeon pea plants artificially infested with the neotropical brown stink bug, Euschistus heros, and their effect on the egg parasitoid, Telenomus podisi. Entomologia Experimentalis et Applicata, v.115, p.227-237, 2005.

PERES, W.A.A.; CORRÊIA-FERREIRA, B.S. Methodology of mass multiplication of Telenomus podisi Ash. and Trissolcus basalis (Woll.) (Hymenoptera: Scelionidae) on eggs of Euschistus heros (Fab.) (Hemiptera: Pentatomidae). Neotropical Entomology v.33, p.457462, 2004.

PIRES, C.; SUJJI, E.; BORGES, M.; SCHMID, F.; ZARBIN, P.H.G.; AZEVEDO, V.C.R.; LACERDA, A.L.; PANTALEÃO, D. Ação cairomonal de componentes do feromônio de alarme do percevejo verde da soja, Piezodorus guildinii, sobre o parasitóide de ovos, Telenomus podisi. Brasília: Embrapa Recursos Genéticos e Biotecnologia, 2001. 22p. (Pesquisa e desenvolvimento, 19).

SUJII, E.R.; COSTA, M.L.M.; PIRES, C.S.S.; COLAZZA, S.; BORGES, M. Inter and intra-guild interactions in egg parasitoid species of the soybean stink bug complex. Pesquisa Agropecuária Brasileira, v.37, p.1541-1549, 2002.

WACKERS, F.L.; LEWIS, W.J. Olfactory and visual learning and their combined influence on host site location by the parasitoid Microplitis croceipes (Cresson). Biological Control, v.4, p.105112, 1994.

Received on May 11, 2005 and accepted on April 4, 2006 